\title{
INCREASE IN WATER-SCARCITY RISK IN A BRAZILIAN DRY-REGION RESERVOIR $^{1}$
}

\author{
MARGARITA MARIA LÓPEZ GIL ${ }^{2 *}$, JOSÉ CARLOS DE ARAÚJO ${ }^{3}$, SUZANA MARIA GICO LIMA \\ MONTENEGRO $^{4}$, JULIANA MARIA DE MORAIS SOBREIRA VALENÇA ${ }^{5}$
}

\begin{abstract}
This study assesses the extent to which silting increases water-scarcity risk, considering the temporal reduction of water availability and increased demand using land use and water-demand scenarios at the transition of Caatinga and Cerrado biomes of the Bocaina reservoir watershed $\left(10^{2} \mathrm{hm}^{3}\right)$, in the Brazilian dry region. Methodological steps were: reservoir silting measured in-situ 20 years after dam construction; climate variables computed with the aid of a conventional station (2005-2014); soil erodibility assessed using 16 soil samples; and topography and land cover estimated based on 21 years of Landsat imagery. Three land use scenarios were generated (invariability, degradation and preservation) with the climate scenario derived from the semi-arid rainfall temporal variability; whereas two water-demand scenarios (invariability and higher efficiency) were a function of the efficiency of the irrigation systems. Water availability was calculated using the volume-yield elasticity (VYELAS) Model. The field results (1985-2015) showed a gross erosion rate of $13.5 \mathrm{Mg} \cdot \mathrm{ha}^{-1} \cdot \mathrm{yr}^{-1}$ in the basin. The annual sediment yield $\left(1.7 \mathrm{Mg} \cdot \mathrm{ha}^{-1}\right)$ and the decadal reservoir silting $(1.0 \%)$ were below regional average due to the low sediment delivery ratio $(12.6 \%)$ in the area. Scenario projections (2040) suggest water demand may double if irrigation methods do not improve, whereas siltation may cause water availability to decrease up to $10 \%$ in the period. In this case, the water-supply reliability will be below the recommended standard value (90\%), regardless of the land use scenario. Nevertheless, simultaneous soil preservation and improved irrigation efficiency can reduce the decadal water-scarcity risk from $82 \%$ (worst scenario) to $17 \%$.
\end{abstract}

Keywords: Caatinga biome. Cerrado biome. Water management. Water demand. Silting.

\section{AUMENTO DO RISCO DE ESCASSEZ HÍDRICA EM UM RESERVATÓRIO DA REGIÃO SECA BRASILEIRA}

RESUMO - Este estudo avalia como o assoreamento aumenta o risco de escassez hídrica, considerando simultaneamente redução temporal da disponibilidade hídrica e aumento da demanda utilizando cenários de uso da terra e demanda hídrica na transição dos biomas Caatinga - Cerrado da bacia do reservatório Bocaina $\left(10^{2} \mathrm{hm}^{3}\right)$, na região seca brasileira. A metodologia seguida: assoreamento medido no reservatório 20 anos após a construção da barragem; variáveis climáticas obtidas de estação convencional (2005-2014); erodibilidade do solo avaliada usando 16 amostras de solo; topografia e cobertura do solo estimadas com base em 21 anos de imagens Landsat. Foram gerados: cenários de uso da terra (invariabilidade, degradação, preservação) com cenário climático derivado da variabilidade temporal da precipitação no Semi-árido; cenários de demanda hídrica (invariabilidade, maior eficiência), função da eficiência dos sistemas de irrigação utilizados. A disponibilidade hídrica calculada usando o Modelo VYELAS. Os resultados de campo (1985-2015) mostraram erosão bruta anual na bacia de $13,5 \mathrm{Mg} \cdot \mathrm{ha}^{-1}$ com produção anual de sedimentos $\left(1,7 \mathrm{Mg} \cdot \mathrm{ha}^{-1}\right)$ e assoreamento decadal do reservatório (1,0\%) abaixo da média regional devido à baixa taxa de aporte de sedimentos $(12,6 \%)$ na área. Os cenários projetados (2040) indicam demanda hídrica duplicando se os métodos de irrigação praticados não melhorarem e disponibilidade hídrica diminuindo (em até 10\%), por assoreamento. Nesse caso, tem-se confiabilidade do suprimento hídrico abaixo do padrão recomendado ( $90 \%)$, independentemente do uso da terra. Todavia, a preservação do solo, simultaneamente com eficiência de irrigação melhorada, reduziria o risco decadal de escassez hídrica de $82 \%$ (pior cenário) para $17 \%$.

Palavra-chave: Bioma Caatinga. Bioma Cerrado. Gestão hídrica. Demanda hídrica. Assoreamento.

\footnotetext{
${ }^{*}$ Corresponding author

${ }^{1}$ Received for publication in $06 / 24 / 2019$; accepted in $07 / 07 / 2020$.

Paper extracted from the doctoral thesis of the first author.

${ }^{2}$ Center of Technology and Urbanism, Universidade Estadual do Piauí, Teresina, PI, Brazil; margot.rd@gmail.com - ORCID: 0000-00026469-9557.

${ }^{3}$ Department of Agricultural Engineering, Universidade Federal do Ceará, Fortaleza, CE, Brazil; jcaraujo@ufc.br - ORCID: 0000-00022649-151X.

${ }^{4}$ Department of Civil Engineering, Universidade Federal de Pernambuco, Recife, PE, Brazil; suzanam@ufpe.br - ORCID: 0000-0002-2520 -5761 .

${ }^{5}$ Instituto Federal de Educação, Ciência e Tecnologia do Piauí, Picos, PI, Brazil; julimsv@gmail.com - ORCID: 0000-0002-1003-3557.
}

Rev. Caatinga, Mossoró, v. 33, n. 4, p. 1025 - 1036, out. - dez., 2020 


\section{INTRODUCTION}

In dry environments, the principal aim of surface reservoirs is to improve water availability. In the Brazilian dry northeastern region, surface reservoirs provide more than $90 \%$ of the water supply (GAISER et al., 2003). Reservoirs are prone to silting, which reduces their storage capacity and changes their morphology towards a more open shape. These alterations increase evaporation and water outflow and reduce water availability (ARAÚJO; GÜNTNER; BRONSTERT, 2006), which is particularly deleterious in water-scarce areas, such as in northeastern Brazil. Simultaneously, water demand expands with time and generates an increasingly unbalanced system. Better knowledge of silting impacts on reservoirs improves the efficiency of local water management, especially in waterscarce environments, where water grants should be judiciously conceded.

Araújo; Güntner; Bronstert (2006) investigated how reservoir silting reduces water availability and aggravates conflicts for water access (GAISER et al., 2003). The authors however did not consider land use or demand scenarios to assess the temporal evolution of the water balance. Including such variables represents an advance in understanding the impact of silting on water scarcity. In addition, it was not known whether the results obtained in the Caatinga could be extrapolated to other biomes. The study was performed in a mesoscale basin at the transition between the semi-arid Caatinga and the sub-humid Cerrado biomes where it is necessary to improve the water-management system because of local water conflicts. In order to justly solve such conflicts, decision makers must be able to accurately evaluate water availability (MARTON; KAPELAN, 2014), which changes over time.

Erosive processes increase with anthropogenic activities in a basin. At the Caatinga biome, especially in the rainy season, cutting vegetation for firewood and opening up areas for livestock and agriculture cause changes in hydrological and sedimentological behavior. Additionally, these anthropogenic activities affect infiltration patterns and produce silting in the reservoir. Thus, reducing water availability (ARAÚJO; GÜNTNER; BRONSTERT, 2006). In the Cerrado biome, which has intense land use (crop yield, burning, deforestation, mining), the accelerated expansion of anthropogenic activities contributes to serious environmental problems associated with soil degradation and water scarcity (HUNKE et al., 2015), such as high rates of reservoir silting (DURÃES; MELLO; BESKOW, 2016; DURÃES; COELHO FILHO; OLIVEIRA, 2016) and low water quality.

Hydrosedimentological studies in watersheds can be supported by computational models, but the required information is generally not available. The Universal Soil Loss Equation (USLE) is considered a reference model because of the ease of implementing the factors in a distributed way (including geoprocessing) and the reliability of its results (BENAVIDEZ et al., 2018). Scenario analysis makes it possible to infer watershed behavior for possible situations of soil use and occupation, as well as conservation practices, without physically intervening in the environment. This study aimed to assess how reservoir silting increases the risk of water scarcity, while considering not only the continuous reduction of availability, but also a progressive increase in demand.

\section{MATERIALS AND METHODS}

The study area was the Bocaina Reservoir Basin $\left(1,070 \mathrm{~km}^{2}\right)$, located in the transition of the Caatinga and Cerrado biomes in the semi-arid region of Piauí (Figure 1). The average annual evaporation is $2,400 \mathrm{~mm}$ and the precipitation is $820 \mathrm{~mm}$, concentrated between February and April. The Bocaina dam was built in 1985 on the intermittent Guaribas River, with initial capacity of $115 \mathrm{hm}^{3}$. The reservoir has different uses, with water conflicts, particularly since 2012, due to a multi-annual drought (ARAÚJO; BRONSTERT, 2016). The conflicts occur among farmers cultivating the river margins near the reservoir and those cultivating downstream to enhance productivity, with the former demanding lower water release and the latter demanding higher. Intensive fish farming in the lake, a growing industry in Brazilian reservoirs, intensifies the conflicts because it demands a reduced release of water. 


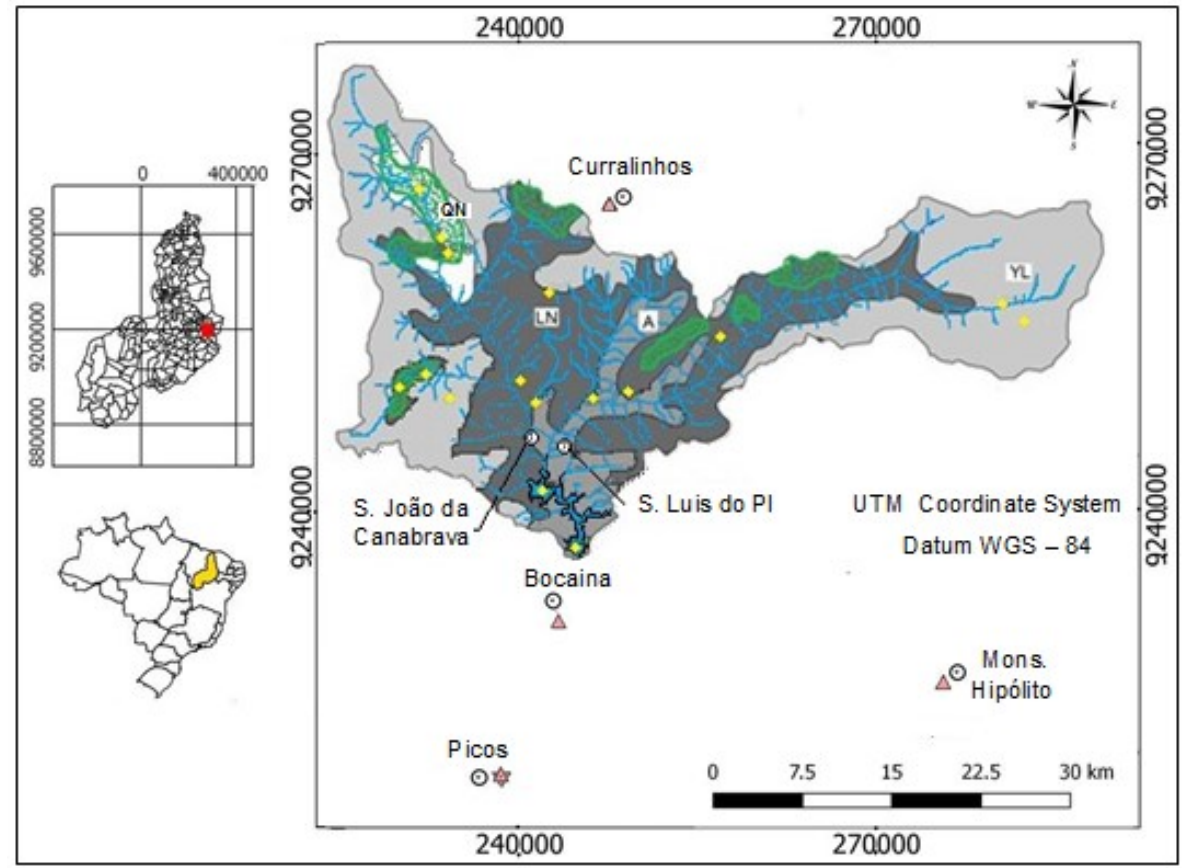

LEGEND

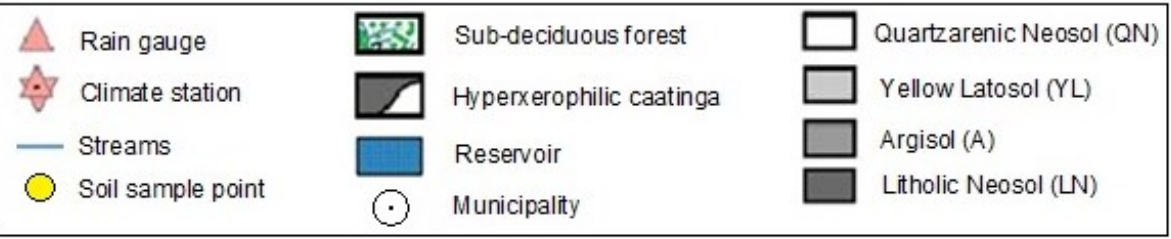

Figure 1. Location of the Bocaina basin, rain gauges and soil sample points.

In-situ assessment of the sediment yield: the sediment yield (SY) of the basin was estimated in Equation 1, where $\Delta \mathrm{M}$ is the accumulated silted mass in the reservoir during the time interval $(\Delta t$, in years); $\mathrm{A}$ is the reservoir catchment area; and $\eta$ is the reservoir trap efficiency, calculated according to Brune (1953). To assess the silting volume variation $(\Delta V)$, we used the bathymetric survey of the reservoir made in 2015 (PIAUÍ, 2016a). Together with the in-situ assessment of the respective dry bulk density $(\rho)$, it was possible to estimate the silted mass. To calculate $\rho$, six sediment samples were taken from the reservoir flooded area.

Equation 2 was used to estimate the sediment delivery ratio (SDR), which was assumed constant for all scenarios. In Equations 2 and 3, $\varepsilon$ corresponds to the annual gross erosion per unit area, computed according to Wischmeier and Smith (1978).

$$
\begin{aligned}
& \mathrm{SY}=\frac{\Delta \mathrm{M}}{\Delta \mathrm{t} \cdot \mathrm{A} \cdot \eta}=\frac{\Delta \mathrm{V} \cdot \rho}{\Delta \mathrm{t} \cdot \mathrm{A} \cdot \eta} \\
& \mathrm{SDR}=\frac{\mathrm{SY}}{\varepsilon}
\end{aligned}
$$

In Equation 3, $\mathrm{R}$ is the annual rainfall erosivity $\left(\mathrm{MJ} \cdot \mathrm{mm} \cdot \mathrm{ha}^{-1} \cdot \mathrm{h}^{-1}\right) ; \mathrm{K}$ is the soil erodibility $\left(\mathrm{Mg} \cdot \mathrm{h} \cdot \mathrm{MJ}^{-1} \cdot \mathrm{mm}^{-1}\right) ; \quad \mathrm{L} \quad$ is the slope-length dimensionless factor; $\mathrm{S}$ is the slope-steepness dimensionless factor ( $\mathrm{L}$ and $\mathrm{S}$ were represented as $\mathrm{LS}$ - dimensionless topographic factor); $\mathrm{C}$ is the land -cover dimensionless factor; and $\mathrm{P}$ is the dimensionless conservation-practice factor. The annual erosivity was calculated by the empirical Equation 4 (GAISER et al., 2003). In Equation 4, $\mathrm{H}_{\mathrm{j}}$ is the total precipitation in the $j$-th month $(\mathrm{mm})$ and $\overline{\mathrm{Ha}}$ is the long-term average annual precipitation $(\mathrm{mm})$ with parameters $(54.883$ and 0.7141$)$ calibrated by López-Gil (2017), using data from Picos INMET climate station (Figure 1) for the period 2005 - 2014. Equation 4 was used here because there were no data available to directly calculate the critical 30-min intensity. The erodibility factor was obtained by Equation 5, where the $\lambda$ factors are parameters: $\lambda_{1}$ is the grain-size factor (Equation 6, where SIL is the silt content and CL the clay content); $\lambda_{2}$ is the soil dimensionless permeability factor (WISCHMEIER; SMITH, 1978); $\lambda_{3}$ is the average weighted particle smaller than 2 $\mathrm{mm}$, given by Equation 7; and $\lambda_{4}$ is the ratio between organic matter and very fine sand contents: $d_{i}$ corresponds to the $\mathrm{i}-$ th particle diameter $(\mathrm{mm})$ and $\mathrm{f}_{\mathrm{i}}$ to the frequency $(\%)$ of the diameter range between $\mathrm{d}_{\mathrm{i}-1}$ and $\mathrm{d}_{\mathrm{i}}$. To compute the erodibility $\mathrm{K}$ factor, 16 soil samples were collected from the prevailing soils and analyzed (Figure 1). 
The topographic factor (LS) was calculated using Equation 8, where $\mathrm{S}_{0}$ is the terrain slope (\%) and $\mathrm{Lr}$ is the slope length $(\mathrm{m})$, while $\mathrm{L}_{\mathrm{R}}$ is given by Equation 9 (GAISER et al, 2003), where $\Sigma \mathrm{L}_{\mathrm{dr}}$ represents the total length of the drainage inside the analyzed area. The land-cover $\mathrm{C}$ factor was based on land use and land cover maps, after classification of the satellite images (Landsat 5) with $30 \mathrm{~m}$ spatial resolution. Satellite imagery was used from three dates (July/1989, July/2000 and August/2010) where it was possible to identify the five prevailing soil use classes in the basin: shrub vegetation, thinned vegetation, exposed soil, agricultural use and water (Figures 2a, 2b and 2c).

$$
\begin{aligned}
& \varepsilon=\mathrm{R} \cdot \mathrm{K} \cdot \mathrm{L} \cdot \mathrm{S} \cdot \mathrm{C} \cdot \mathrm{P} \\
& R=\sum_{j=1}^{12} 54.883 \cdot\left(\mathrm{H}_{j}^{2} / \overline{\mathrm{Ha}}\right)^{0.7141} \\
& \mathrm{~K}=7.48 \times 10^{-6} \cdot \lambda_{1}+4.48 \times 10^{-3} \cdot \lambda_{2}-6.312 \times 10^{-2} \cdot \lambda_{3}+1.0396 \times 10^{-2} \cdot \lambda_{4} \\
& \lambda_{1}=\mathrm{SIL} \% \cdot(100-\mathrm{CL} \%) \\
& \lambda_{3}=\operatorname{EXP}\left(\sum_{\mathrm{i}} \mathrm{f}_{\mathrm{i}} \cdot \operatorname{Ln}\left(\frac{\mathrm{d}_{\mathrm{i}}+\mathrm{d}_{\mathrm{i}-1}}{2}\right)\right) \\
& \mathrm{L} . \mathrm{S}=9.84 \times 10^{-3} \cdot \mathrm{L}_{\mathrm{R}}^{0.65} \cdot S_{0}^{1.18} \\
& \mathrm{~L}_{\mathrm{R}}=\mathrm{A} /\left(4 \cdot \sum \mathrm{L}_{\mathrm{dr}}\right)
\end{aligned}
$$

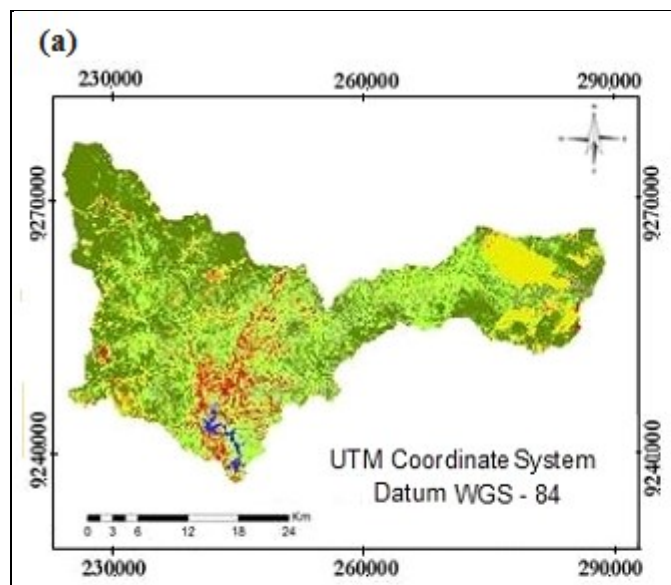

(b)

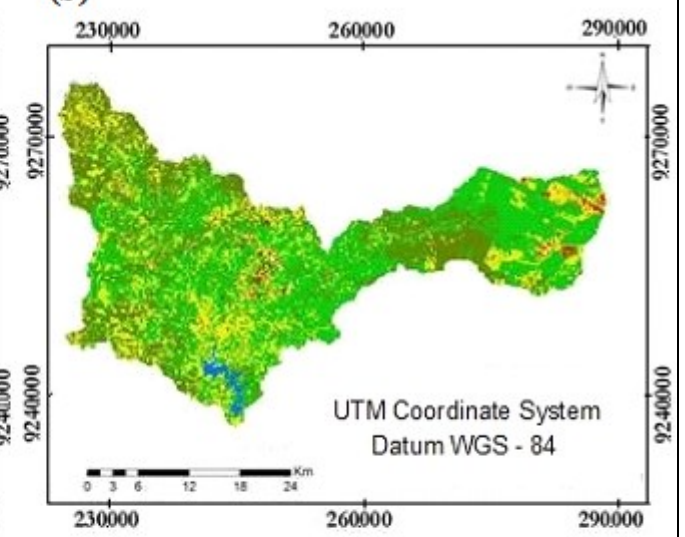

(c)
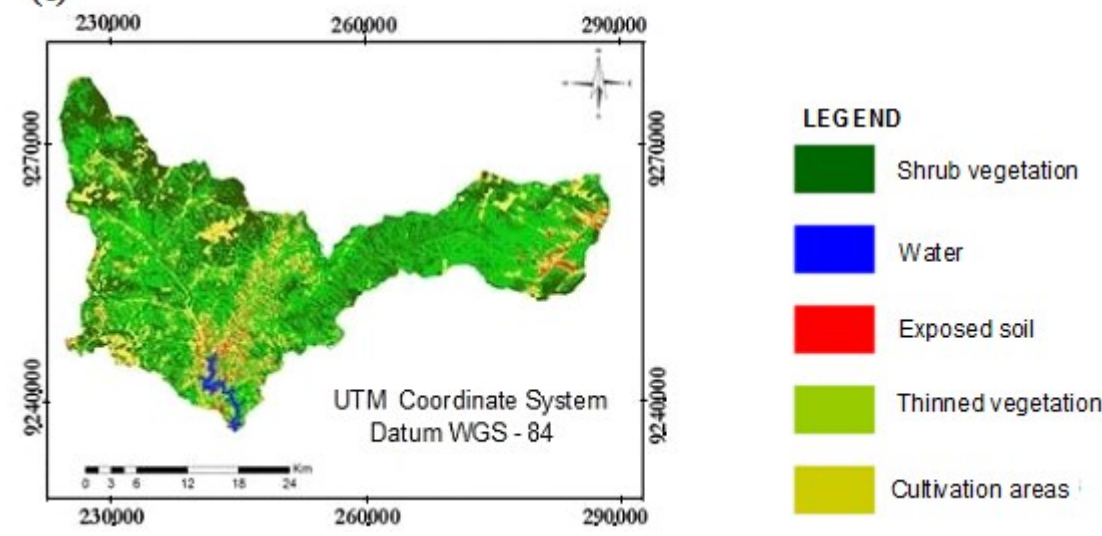

Figure 2. Land use-land cover in the Bocaina basin (a) year 1989, (b) year 2000, (c) year 2010

There was a ground-truthing campaign in June 2016 to identify land use in the catchment area of Bocaina dam. In terms of agriculture, the main crops were maize (Zea mays), beans (Phaseolus vulgaris) and manioc (Manihot esculenta), usually cultivated in association. The following was assumed: $\mathrm{C}=0.039$ for agriculture (LIMA et al., 2014), $C=0.017$ for shrub vegetation and $C=0.006$ for thinned vegetation (SANTOS et al., 2014). Furthermore we assumed $\mathrm{P}=1$ considering that in 
the area no conservation practice was identified.

Equation 3 was processed using map algebra with Landsat 5 images (30 $\mathrm{m}$ spatial resolution); the raster calculator tool of the ArcGis 9.3 and the surface digital model SRTM (Shuttle Radar Topographic Mission, 2000) at the 1:250 000 scale. In order to analyze the temporal dynamics of land use, a supervised classification (MaxVero) of the satellite imagery was established that considers weighted distances between averaged digital class levels, while the themes were identified on site. For image processing, map generation and manipulation, we used the 4:3:2 band composition of SPRING 4.3.3.

Reservoir silting scenarios: the investigation considered three reservoir silting scenarios (2010 2040); all of which directly depended on rainfall erosivity and the evolution of land use. In the scenarios, rainfall varied for different horizons considering, as in Krol et al (2011), the most critical values of rainfall variation $(+10 \%$ of rainfall in the rainy season and $-20 \%$ in the dry season). The five prevailing classes of land use and vegetation cover identified (shrub vegetation, thinned vegetation, exposed soil, agricultural use and water) were used to access the $\mathrm{C}$ factor.

Silting scenario (S1) - invariability: the land use conditions in the year 2010 are assumed invariant until 2040; that is, the area fractions of exposed soil (3.2\%), agriculture (18.3\%), shrub vegetation $(25.9 \%)$, thinned vegetation $(51.9 \%)$, and the area flooded by dams $(0.7 \%)$ would not change throughout the simulation period. Silting scenario (S2) - degradation (high erosion): we assumed the most erodible land uses (exposed soil and agriculture) would have the largest area fractions of the imagery years $(1989,2000$ and 2010; see Figure 2): $8.2 \%$ (as in 1989) and $24.9 \%$ (as in 2000), respectively. The shrub vegetation would occupy $26.4 \%$ of the area (as in 2000) and the flooded area fraction was considered to be $0.7 \%$ (as in 1989 and 2000). The hypothesis of further dam construction was not assumed in the scenarios because the number of dams in the region has achieved the hydrological saturation point. In Scenario S2, therefore, the thinned vegetation - the cover that mostly reduces erosion (SANTOS et al., 2014) would occupy $39.8 \%$ of the catchment area. Silting scenario (S3) - preservation (low erosion).We assumed the soil conservation practices would improve and larger areas would be destined for lowerosive land uses: agriculture would reduce the C.P factor to 0.013 (instead of 0.039 ), occupying $18.3 \%$ of the area (as in 2010); 25.9\% of the area (as in 2010) would be composed of shrub vegetation; and $51.9 \%$ of the area (as in 2010) would be covered by thinned vegetation. The flooded area would also be assumed to be $0.7 \%$ (as in 1989 and 2000), whereas the reforestation (C.P $=0.010$ ) area would cover $1.4 \%$, reducing the exposed soil from $3.2 \%$ to $1.8 \%$ of the total surface.

Water demand scenarios: we evaluated the following water demands associated with the Bocaina reservoir (for the years 2010 and 2040): irrigation, urban human consumption, animal consumption and ecological discharge. In the basin, irrigation has the highest consumptive use, (almost $85 \%$ for 2010 ) with a weighted average efficiency of $55 \%$ (ANA, 2013). Flooding is the most frequently used method and the irrigated area of the region is presently growing at a rate of $1.11 \%$ per year (IBGE, 2015). The demand scenario D1 (invariability) assumes irrigation efficiency remains at the current level (55\%); while the demand scenario D2 (enhanced irrigation efficiency) assumes admits that irrigation efficiency rises to $70 \%$, according to the plan proposed by ANA (2013). The future demands for human consumption were obtained from Piauí (2011), while animal population data were provided by IBGE (2015). Since all the rivers in the study basin are intermittent, the ecological discharges were assumed to be $10 \%$ of the reference discharge $Q_{90}$, defined as the reservoir water yield with an annual reliability of $90 \%$ (CAMPOS, 2010). The criterion for the calculation of the ecological discharge is the same used in the Brazilian Semi-arid Region by Vestena et al. (2012).

Water availability and water-scarcity risk: we assessed reservoir water availability using the VYELAS model (Volume-yield elasticity: ARAÚJO; GÜNTNER; BRONSTERT, 2006), which generates a curve that expresses the water yield as a function of its respective annual reliability. The model simulates the reservoir water balance using synthetic inflow series generated by Monte Carlo method, as in Campos (2010). For a given water yield, the model calculates the annual reliability. The model takes into account the reservoir operation rules implemented by basin committees (ARAÚJO; BRONSTERT, 2016). The reservoir's morphology is assumed to be represented by Equation 10 (CAMPOS, 2010). The input data of the model is presented in Table 1.

$$
\mathrm{V}=\alpha \cdot h^{3}
$$


M. M. L. GIL et al.

Table 1. Input data of the VYELAS model for simulations of the Bocaina Reservoir.

\begin{tabular}{|c|c|c|}
\hline Data & Source & Values \\
\hline $\begin{array}{l}\text { River inflow: annual average and } \\
\text { variation coefficient }(\mathrm{CV}) \text {. }\end{array}$ & $\begin{array}{l}\text { Hydrographs (period 2000-2015) from registered } \\
\text { data by DNOCS-PI (Departamento Nacional de } \\
\text { Obras Contra as Secas). }\end{array}$ & $\begin{array}{l}\text { Annual average }= \\
69.4 \mathrm{hm}^{3} \\
\mathrm{CV}=0.40\end{array}$ \\
\hline $\begin{array}{l}\text { Morphological coefficient } \alpha \text { and } \\
\text { reservoir storage capacity in the } \\
\text { construction year (1985). }\end{array}$ & PIAUÍ (2016b). Height-area-volume curves. & $\begin{array}{l}\text { Coefficient } \alpha=1,667 \\
\text { Capacity }=115 \mathrm{hm}^{3}\end{array}$ \\
\hline $\begin{array}{l}\text { Morphological coefficient } \alpha \text { and } \\
\text { reservoir storage capacity in the } \\
\text { bathymetric survey year }(2015) .\end{array}$ & PIAUÍ (2016a). Height-area-volume curves. & $\begin{array}{l}\text { Coefficient } \alpha=2,197 \\
\text { Capacity }=111 \mathrm{hm}^{3}\end{array}$ \\
\hline $\begin{array}{l}\text { Evaporation rate of the dry season } \\
\text { (CAMPOS, 2010) }\end{array}$ & $\begin{array}{l}\text { Class-A pan from Picos Climate Station operated by } \\
\text { Instituto Nacional de Meteorologia (INMET). } \\
\text { For dryland reservoirs, multiply class-A pan by } 0.70 \\
\text { - in Mamede et al.(2012) Data period:1976 - } 1990\end{array}$ & $\begin{array}{l}\text { In the dry season, the average } \\
\text { evaporation rate is } 1.72 \mathrm{~m} \text { per } \\
\text { year }\end{array}$ \\
\hline
\end{tabular}

In Equation $10, \mathrm{~V}$ is the volume $\left(\mathrm{m}^{3}\right), \alpha$ is the non-dimensional morphological coefficient, and $\mathrm{h}$ is the water level of the reservoir. Due to silting, it was not possible to estimate morphological alterations for the year 2040 with the method that we used to assess the reservoir silting (Equations 1, 2, 3, 4, 5, 6, 7 , 8, 9 and 10), i.e., the method cannot assess the morphological coefficient $\alpha$ in the future. In order to overcome this obstacle, we used the concept of water -yield elasticity $(\Phi)$, defined by Equation 11 (ARAÚJO; GÜNTNER; BRONSTERT, 2006). Elasticity $(\Phi)$ was assessed for several reliability levels based on water yield $(\mathrm{Qw})$, calculated as in Araújo; Güntner; Bronstert (2006) and on storage capacity (volume V) in 1985 and in 2015. We assumed that the average values $(1985-2015)$ of the parameter $\Phi$ remained constant for the period 2015 2040.

$$
\Phi=\frac{\Delta Q \mathrm{w} / \mathrm{Qw}}{\Delta \mathrm{V} / \mathrm{V}}
$$

The water-scarcity risk $(\zeta)$ of a given reservoir can be assessed as the probability of a flaw in the provision of at least one in $n$ years (Equation 12 , where $G$ is the annual water supply reliability).

$$
\zeta=1-G^{n}
$$

\section{RESULTS AND DISCUSSION}

In-situ assessment of sediment yield and reservoir silting: the annual average erosivity estimated for the Bocaina reservoir basin (19852015) was $3,200 \mathrm{MJ} \cdot \mathrm{mm} \cdot \mathrm{ha}^{-1} \cdot \mathrm{h}^{-1}$. According to Table 2, Argisol and Quartzarenic Neosol are the soils most susceptible to erosion within the area. This however does not significantly affect the global basin erosion, since these soils occupy a small area. The Litholic Neosols and yellow Latosols, with high and medium erosion potential, occupy the largest areas. But they are located in flat areas of the highest levels of the basin, where the predominant land use and vegetation-cover causes the lowest sediment yield. The cultivation areas (with greater erosive potential among existing vegetation-cover and land use) are located mainly in the hillslopes near the banks of rivers.

The average spatial topographic factor (LS) was calculated as 2.86. All these elements resulted in the annual gross erosion of the basin (1985-2015) of up to $225 \mathrm{Mg} \cdot \mathrm{ha}^{-1}$, (Figure 3) but with a moderate annual average value $\left(13.5 \mathrm{Mg} \cdot \mathrm{ha}^{-1}\right)$.

Table 2. Erodibility factor $(\mathrm{K})$ estimated for the specific soil classes of the Bocaina reservoir basin

\begin{tabular}{lcc}
\hline Soil class & Average $\mathrm{K}\left(\mathrm{Mg} \cdot \mathrm{h} \cdot \mathrm{MJ}^{-1} \cdot \mathrm{mm}^{-1}\right)$ & Area $(\%)$ \\
\hline Argisol & 0.052 & 10.5 \\
Yellow Latosol & 0.028 & 44.8 \\
Litholic Neosol & 0.042 & 39.7 \\
Quartzarenic Neosol & 0.034 & 5.0 \\
\hline Weighted average & 0.036 & \\
\hline
\end{tabular}



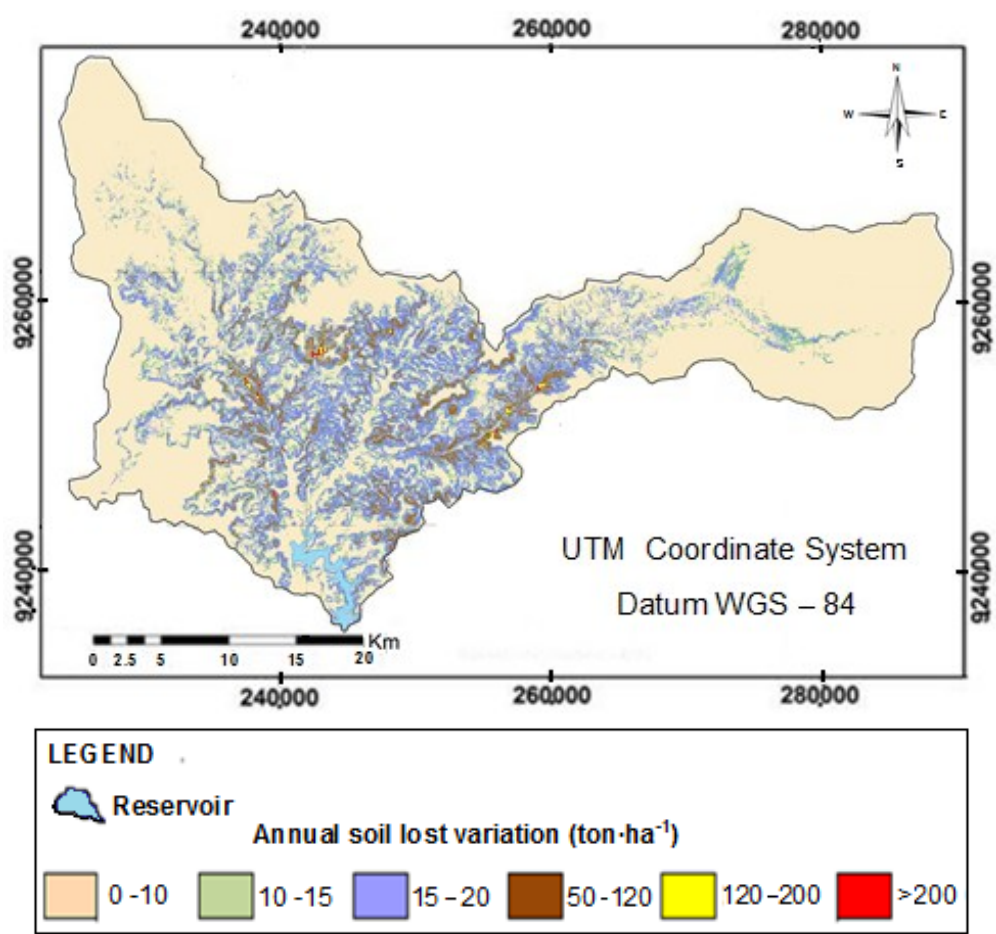

Figure 3. Annual gross erosion in the Bocaina Basin (1985-2015).

Figure 4, which compares reservoir morphology in 1985 and in 2015, shows larger accumulation values both in the delta and in the upper reaches (backwater sediment). The bathymetry (PIAUÍ, 2016a) indicated a reduction in the Bocaina storage capacity of $3.63 \mathrm{hm}^{3}$, or $3.2 \%$ of the initial capacity, leading to a decadal volumetric reduction of $1.0 \%$. The silted soil dry bulk density was $1.44 \mathrm{Mg} \cdot \mathrm{m}^{-3}$, whereas the trap efficiency was 0.97
(BRUNE, 1953): this led to an annual sediment aggradation rate of $0.12 \mathrm{hm}^{3}$ in the period. Based on field data, the estimated sediment delivery ratio of the basin was $12.6 \%$, which was considered low, generating a low annual sediment yield (1.7 Mg $\left.\mathrm{ha}^{-1}\right)$. According to Medeiros et al. (2014), despite the high erosivity and moderate-to-high soil erodibility, the sediment yield in the region is usually low, leading to an equally low reservoir silting.

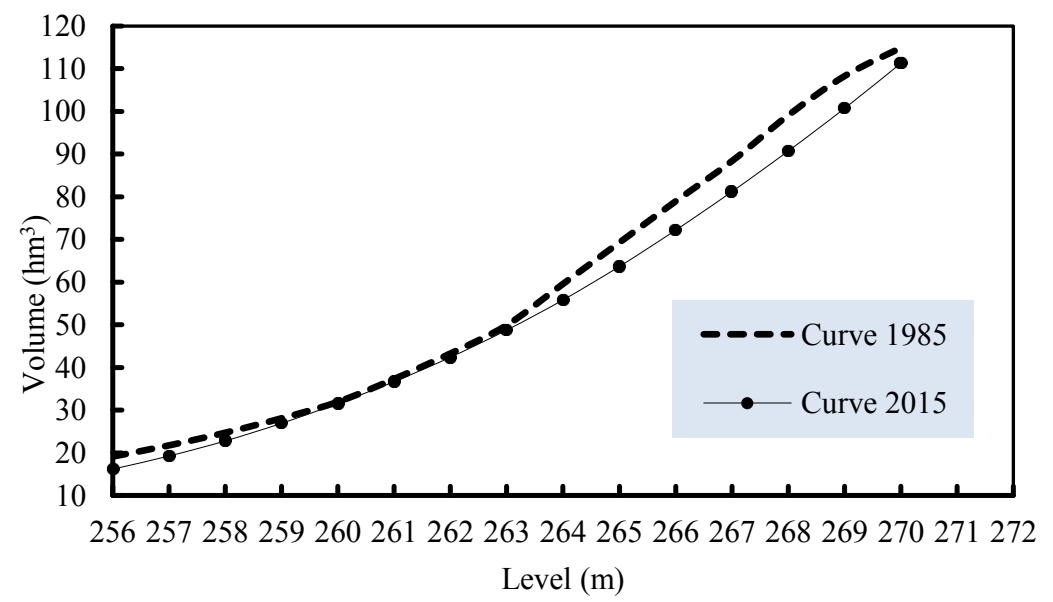

Figure 4. Curve height (level) versus volume for the Bocaina reservoir in the construction year (1985) and the control (bathymetry) year (2015).Source: Piauí (2016a), (2016b).

One of the main causes of the low sediment delivery ratio is the long dry season that limits the runoff transport capacity and induces low water and soil connectivity (MEDEIROS et al., 2014).
Literature confirms the low sediment delivery ratio in the Caatinga Biome: $16 \%$ in Várzea do Boi and $12 \%$ in São Mateus (GAISER et al., 2003), 11\% in Tapacurá (SILVA; SANTOS; MONTENEGRO, 
2013) and 7\% in Benguê (MEDEIROS et al., 2014). The Cerrado Biome, in contrast, typically shows higher values: $66 \%$ in Paraopeba (DURÃES; MELLO; BESKOW, 2016) and $28 \%$ in the Upper Iguaçu (DURÃES; COELHO FILHO; OLIVEIRA, 2016); although in some areas there are also low values of connectivity (thus, low delivery ratio), as in Água Fria (6\%: SILVA; SCHULZ, 2007) and in some sub-basins of the Paraopeba River (as low as 9\%: DURÃES; MELLO; BESKOW, 2016).

The measured volumetric silting rate of the Bocaina reservoir (1985 - 2015) was $1.01 \%$ per decade, almost half of the average value of the Caatinga reservoirs $(1.85 \%)$ and similar to some basins, such as Acarape do Meio (1.06\%) (GAISER et al., 2003). In the dry Cerrado, the silting rates are similar to those of the Caatinga, e.g., in the Três Irmãos reservoir basin (ALBERTINI; MATOS; MAUAD, 2010). In the humid areas of the biome, silting rates can be excessively high. Carvalho, Guilhon and Trindade (2000), for example, studied the Itiquira Reservoir (storage capacity of $5 \mathrm{hm}^{3}$ and catchment area of $5,083 \mathrm{~km}^{2}$ ), which consists of a basin with a high erosive potential due to the prevailing land use for livestock, mining and mechanized agriculture. In addition, the reservoir presents a high catchment-area-to-storage-capacity ratio $\left(1,017 \mathrm{~km}^{2} \cdot \mathrm{hm}^{-3}\right)$, which induces high vulnerability towards siltation. If constructed, the Itiquira Dam would be completely silted within eight years (CARVALHO; GUILHON; TRINDADE, 2000), at a rate 40 times higher than that observed in the Caatinga.

Regarding the low sedimentation rate of the Bocaina Reservoir, two factors stand out. Gaiser et al. (2003) showed there is a causal relation between the catchment area and the reservoir storage capacity: small ratios indicate the contribution of water and sediment to the reservoir is small. In Bocaina, the ratio is $9.1 \mathrm{~km}^{2} \cdot \mathrm{hm}^{-3}$, almost half of the average of the Caatinga $\left(16.7 \mathrm{~km}^{2} \cdot \mathrm{hm}^{-3}\right)$, which in part justifies the reduced siltation. The second factor is the preservation status of the watershed vegetation. The forested area (both shrub and thinned vegetation) occupied $77 \%$ of the territory in $1989,71 \%$ in 2000 and $79 \%$ in 2010 . This shows that the deforestation observed between 1989 and 2000 did not prevail in the subsequent period (2000 2010), when a vegetative recovery took place, in full agreement with the results of a remote-sensing based investigation by Redo, Aide and Clark (2012).

In terms of land use, there is the predominance of thinned vegetation $(40 \%$ in 1989 , $45 \%$ in 2000 and $52 \%$ in 2010), for which the land use and occupation factor (WISCHMEIER; SMITH, $1978)$ is the smallest $(\mathrm{C}=0.006)$ among all the land uses identified in the basin. The thinning technique favors the penetration of light and consequently the formation of the herbaceous extract, which reduces water velocity and enhances sediment deposition.

Reservoir silting and its impact on water availability: based on simulations, the average annual erosivity in 2040 is expected to be 3,309 $\mathrm{MJ} \cdot \mathrm{mm} \cdot \mathrm{ha}^{-1} \cdot \mathrm{h}^{-1}, 2.8 \%$ higher than the historical average for the period $1985-2015$. Table 3 presents the main estimates of gross erosion and silting of the reservoir for the historical period (1985-2015), silting scenarios and the water availability of Bocaina for several reliability levels.

Table 3. Annual erosion, sediment yield, silting, storage capacity, volume-yield elasticity $(\Phi)$ and water availability (Qw, for different annual reliability levels G) in the Bocaina Reservoir for the years 1985, 2015, and 2040; considering the silting scenarios S1, S2, and S3.

\begin{tabular}{|c|c|c|c|c|c|c|}
\hline & \multirow[b]{2}{*}{1985} & \multirow[b]{2}{*}{2015} & \multirow[b]{2}{*}{$\Phi(-)$} & \multicolumn{3}{|c|}{2040} \\
\hline & & & & S1 & S2 & S3 \\
\hline Erosion $\varepsilon\left(\mathrm{Mg} \cdot \mathrm{ha}^{-1}\right)$ & $(-)$ & 13.5 & $(-)$ & 13.5 & 28.1 & 8.6 \\
\hline Sediment yield $\left(\mathrm{Mg} \cdot \mathrm{ha}^{-1}\right)$ & $(-)$ & 1.7 & $(-)$ & 1.7 & 3.5 & 1.1 \\
\hline Silting since $1985\left(\mathrm{hm}^{3}\right)$ & $(-)$ & 3.6 & $(-)$ & 7.3 & 11.9 & 6.1 \\
\hline Silting since $1985(\%)$ & $(-)$ & 3.2 & $(-)$ & 6.3 & 10.4 & 5.3 \\
\hline Storage capacity $\left(\mathrm{hm}^{3}\right)$ & 115.0 & 111.4 & $(-)$ & 107.7 & 103.1 & 108.9 \\
\hline Qw $[\mathrm{G}=99 \%]\left(\mathrm{hm}^{3}\right)$ & 41.88 & 41.20 & 0.519 & 40.50 & 39.63 & 40.73 \\
\hline $\mathrm{Qw}[\mathrm{G}=95 \%]\left(\mathrm{hm}^{3}\right)$ & 48.20 & 46.70 & 0.994 & 45.16 & 43.24 & 45.66 \\
\hline Qw $[\mathrm{G}=90 \%]\left(\mathrm{hm}^{3}\right)$ & 52.11 & 50.34 & 1.085 & 48.52 & 46.26 & 49.11 \\
\hline Qw $[\mathrm{G}=80 \%]\left(\mathrm{hm}^{3}\right)$ & 57.51 & 55.94 & 0.872 & 54.33 & 52.32 & 54.85 \\
\hline $\mathrm{Qw}[\mathrm{G}=70 \%]\left(\mathrm{hm}^{3}\right)$ & 62.28 & 60.51 & 0,908 & 58.69 & 56.43 & 59.28 \\
\hline
\end{tabular}


By 2040 and according to the trend scenario $\mathrm{S} 1$, the Bocaina silting is expected to be $7.3 \mathrm{hm}^{3}$, which corresponds to a rate of $1.1 \%$ per decade. In the least favorable scenario (S2), silting can be as high as $11.9 \mathrm{hm}^{3}$, which represents a $1.8 \%$ volume loss per decade. The most favorable scenario (S3) estimates $6.1 \mathrm{hm}^{3}$ silting, which implies a rate of $0.9 \%$ per decade. The $90 \%$ reliability water yield $\left(\mathrm{Q}_{90}\right)$ is $73 \%$ of the average annual inflow (20002015) (Table 1) to the reservoir $\left(69.4 \mathrm{hm}^{3}\right)$, a very high ratio for the Caatinga Biome, but typical for wetter tropical environments (HUNKE et al., 2015), such as the Cerrado. Table 3 also shows that $\mathrm{Q}_{90}$ has decreased more intensively with time (1985-2015) than the water yield with other reliability levels $(\mathrm{G})$ : $3.4 \%$; whereas for $\mathrm{G}=70 \%$, it decreased by $2.8 \%$; and for $\mathrm{G}=99 \%$, by $1.6 \%$. This feature is also remarkable when evaluating the volume-yield elasticity $(\Phi)$, which presents its maximum value for $\mathrm{G}=90 \%$.

The average $\Phi$ value is 0.88 , close to that observed by Araújo; Güntner; Bronstert (2006): 0.80 , for seven reservoirs in the Brazilian Semi-arid Region. The above-mentioned remarks indicate the hydrology of the focus watershed has characteristics of both biomes. Water availability $\left(\mathrm{Q}_{90}\right)$ in 2040 is expected to vary from $46 \mathrm{hm}^{3}$ per year in the higherosion scenario to $49 \mathrm{hm}^{3}$ per year in the environmental-protection scenario. This indicates that conservationist practices can increment water availability by $6 \%$.

Water demand and the risk of water scarcity: the average water demand increases for the period 2010 - 2040 (Table 4).

Table 4. Water demand from the Bocaina dam $\left(\mathrm{hm}^{3}\right)$ for 2010 and 2040, for the two demand scenarios D1 and D2.

\begin{tabular}{lccc}
\hline & & \multicolumn{2}{c}{2040} \\
\cline { 3 - 4 } Demand & 2010 & & $\mathrm{D} 1$ \\
\hline Human consumption & & 9.5 & 9.5 \\
Animal consumption & 0.2 & 0.4 & 0.4 \\
Irrigation & 20.9 & 36.2 & 28.5 \\
Ecological discharge & 3.7 & 3.7 & 3.7 \\
\hline Total & 24.8 & 49.8 & 42.1 \\
\hline
\end{tabular}

The current demands of the Bocaina system can be met with a high reliability level (above 95\%) because of the still low water demand from the reservoir. At present, there is no human-supply system from the reservoir due to gaps in the sanitation policy; thus, the area is presently supplied by a network of wells. This is expected to change before 2040 because of the construction of a pipeline system designed to supply the urban areas of the dam surroundings and will increase water outtake from the reservoir at $9.5 \mathrm{hm}^{3}$ per year. The animal-supply demand is expected to double between 2010 and 2040. The most demanding sector, irrigation, uses $84 \%$ of total current water supply.

If the irrigation efficiency remains at the same level as today $(55 \%$, scenario D1), the sector needs will increase from $20.9 \mathrm{hm}^{3}$ per year to $36.2 \mathrm{hm}^{3}$ per year. If, however, there is an improvement of the irrigation efficiency to $70 \%$ (scenario D2), the sector would demand $28.5 \mathrm{hm}^{3}$ per year. In synthesis, the results show how much water availability decreases
(Table 3) while demand increases (Table 4), which is particularly worrisome in water-scarce regions. Thus, a planned intervention could increase irrigation efficiency to $70 \%$ and can generate a considerable water surplus $\left(7.7 \mathrm{hm}^{3}\right)$ per year, which would be enough to meet $81 \%$ of the total human demand of the Bocaina influence area. This provides an insight into the relevance of water-demand management, as opposed to the monotonic approach of water-supply management, which has characterized the regional water policy for more than a Century (ARAÚJO; BRONSTERT, 2016).

The water-availability decline of the Bocaina Reservoir was due to the silting between 1985 and 2015 and averaged 3\% (Table 3). To understand the implications of this reduction, it is helpful to analyze the risk of water scarcity, as presented in Table 5 , which shows the superposition of both effects and the decadal risk of water scarcity in each composed scenario. 
M. M. L. GIL et al.

Table 5. Analysis of combined silting (S1, S2, and S3) and demand (D1 and D2) scenarios for the year 2040 in the Bocaina Reservoir: annual reliability of the water demand and risk of decadal water scarcity.

\begin{tabular}{lccc}
\hline \multicolumn{1}{c}{ Scenarios } & S1 & S2 & S3 \\
& (invariability) & (degradation) & (preservation) \\
\hline & Annual demand reliability in 2040 & \\
D1 (invariability) & 0.88 & 0.84 & 0.89 \\
D2 (enhanced irrigation efficiency) & 0.98 & 0.96 & 0.98 \\
\hline \multicolumn{4}{c}{ Risk of decadal water scarcity in 2040 } \\
D1 (invariability) & 0.72 & 0.82 & 0.68 \\
D2 (enhanced irrigation efficiency) & 0.20 & 0.32 & 0.17 \\
\hline
\end{tabular}

The trend scenario (S1-D1) indicates an excessively high risk of decadal water scarcity (72\%), which means that an intervention is advisable so as to avoid a water collapse in the area. For demand scenario D1, water reliability would be inferior to the desirable level $(90 \%)$, whatever the silting scenario, which is a strong indicator that this scenario will lead to a non-sustainable situation, considering that a $90 \%$ annual reliability is the planning parameter for the Brazilian dry region (CAMPOS, 2010). Contrastingly, an improvement of irrigation efficiency would generate high reliability (above $95 \%$ ) of water supply by 2040 .

The worst combined scenario (S2-D1) shows an extremely high decadal risk of water shortage $(82 \%)$ in 2040 , caused by the combination of environmental degradation (S2) and the lack of a water-demand policy (D1). In contrast, the combination of an environmental conservation policy (S3) and an improved irrigation technology (D2) has the potential to reduce this risk to $17 \%$. The beneficial potential of changing the land use can be noticed by comparing the scarcity risk of the combined scenarios S2-D1 with that of S3-D1, which would considerably lower the risk from $82 \%$ to $68 \%$. Nonetheless, the benefit caused by changes in irrigation efficiency is even higher: the scarcity risk can be reduced from $82 \%$ (S2-D1) to $32 \%$ (S2D2), which shows the relevance of a water-demand management for the hydric policy of the Brazilian dry region.

\section{CONCLUSION}

Field measurements (1985 - 2015) indicated gross erosion in the watershed Bocaina reservoir of $13.5 \mathrm{Mg} \cdot \mathrm{ha}^{-1} \cdot \mathrm{yr}^{-1}$, sediment delivery ratio of $12.6 \%$ and annual sediment yield of $1.7 \mathrm{Mg}^{-h^{-1}}{ }^{-}$. Despite the high gross erosion, sediment yield was low mainly due to hydrological constraints, which limit sediment-transport capacity and reservoir silting $(1.0 \%$ per decade). The average volume-yield elasticity was 0.88 , i.e., the decadal wateravailability reduction was $0.88 \%$.

Considering the increase in water demand until 2040 in the scenario without improving the efficiency of irrigation methods applied in the basin, supply reliability is expected to be unsatisfactory (below 90\%), regardless of the silting scenario. Nonetheless, if irrigation efficiency rises from 55\% to $70 \%$, supply reliability surpasses $95 \%$ for any silting scenario. The integration of both strategies (soil preservation and increased irrigation efficiency) can reduce the decadal water-scarcity risk from $82 \%$ (worst scenario) to $17 \%$. Between both strategies, demand management has proven to be more effective.

The results of this research are a relevant guide for decision makers in planning the supply of water-demands in the Bocaina Reservoir, considering the existing water conflicts and as support for the management of water resources in such a water-scarce region. Among the relevant issues that were not tackled in this investigation, we mention (a) the impact of surface-reservoir siltation on water quality and hence, on water availability; and (b) the contribution of a water-reuse policy (integrated with environmental preservation and demand management policies) to the societal adaptation to water-scarcity situations.

\section{ACKNOWLEDGMENTS}

The authors acknowledge the Brazilian Capes Foundation (DINTER UFPE/IFPI/UESPI - Civil Engineering), the Brazilian National Research Council CNPq (grants 301677/2015-8 and 308464/2015-0), and the following institutions for providing data: INMET (Recife), EMBRAPA Solos, UEP (Recife), DNOCS/PI, and SEMAR/PI.

\section{REFERENCES}

ALBERTINI, L. L.; MATOS, A. J. S.; MAUAD F. F. Cálculo do volume e análise da deposição de sedimentos do reservatório de Três Irmãos. Revista Brasileira de Recursos Hídricos, 15: 57-67, 2010.

AGÊNCIA NACIONAL DE ÁGUAS - ANA. Relatório de campanha de cadastramento Rio 
Guaribas - Reservatório Bocaina - Piauí. Relatório $\quad \mathrm{N}^{\mathrm{o}}$ 001/2013/GECAD/SFI, Doc. 00000.025655/2013-13. Brasília, 2013. 61 p.

ARAÚJO, J. C.; GÜNTNER, A.; BRONSTERT, A. Loss of reservoir volume by sediment deposition and its impact on water availability in semiarid Brazil. Hydrological Sciences, 51: 157-170, 2006.

ARAÚJO, J. C.; BRONSTERT, A. A method to assess hydrological droughts in semi-arid environments and its application to the Jaguaribe River basin, Brazil. Water International, 41: 213230, 2016.

BENAVIDEZ, R. et al. A review of the (Revised) Universal Soil Loss Equation (R) USLE: with a view to increasing its global applicability and improving soil loss estimates. Hydrology and Earth System Sciences, 22: 6059-6086, 2018.

BRUNE, G. M. Trap efficiency of reservoirs. American Geophysical Union, 34: 407- 418, 1953.

CAMPOS, J. N. B. Modeling the yield-evaporationspill in the reservoir storage process: The regulation triangle diagram. Water Resources Management, 24: 3487-3511, 2010.

CARVALHO, N. O.; GUILHON, L. G. F.; TRINDADE, P. A. O assoreamento de um pequeno reservatório - Itiquira, um estudo de caso. Revista Brasileira de Recursos Hídricos - RBRH, 5: 69-79, 2000.

DURÃES, M. F.; MELLO, C. R.; BESKOW, S. Sediment yield in Paraopeba river basin - MG, Brazil. International Journal of River Basin Management, 14: 367-377, 2016.

DURÃES, M. F.; COELHO FILHO, J. A. P.; OLIVEIRA, V. A. Vulnerabilidade à erosão hídrica e taxa de aporte de sedimentos na Bacia Hidrográfica do Alto Rio Iguaçu - PR. Revista Brasileira de Recursos Hídricos, 21: 728-741, 2016.

GAISER, T. et al. Global change and regional impacts - Water availability and vulnerability of ecosystems and society in the semiarid northeast of Brazil, Berlin, Springer Verlag, 2003. 428 p.

HUNKE, P. et al. The Brazilian Cerrado: assessment of water and soil degradation in catchments under intensive agricultural use. Ecohydrology, 8: 1154 1180, 2015.

INSTITUTO BRASILEIRO DE GEOGRAFIA E ESTATÍSTICA - IBGE. Sistema IBGE de Recuperação Automática. SIDRA. Disponível em: $<$ https://sidra.ibge.gov.br>. Acesso em: 01. abr.
2015 .

KROL, M. S. et al. Sustainability of small reservoir sand large scale water availability under current conditions and climate change. Water Resources Management, 25: 3017-3026, 2011.

LIMA, P. L. T. et al. Soil loss by water erosion in areas under maize and jack beans intercropped and monocultures. Ciência e Agrotecnologia, 38: 129$139,2014$.

LÓPEZ-GIL, M. M. Análise de cenários de produção de sedimentos na relação ofertademanda hídrica da Barragem Bocaina - PI. 2017. 251 f. Tese (Doutorado em Engenharia Civil: Área de Concentração em Tecnologia Ambiental e Recursos Hídricos). - Universidade Federal de Pernambuco, Recife, 2017.

MAMEDE, George L. et al. Overspill avalanching in a dense reservoir network. Proceedings of the National Academy of Sciences, 109: 7191-7195, 2012.

MARTON, D.; KAPELAN Z. Risk and reliability analysis of open reservoir water shortages using optimization. Procedia Engineering, 89: 14781485,2014

MEDEIROS, P. H. A. et al. Connectivity of sediment transport in a semiarid environment: a synthesis for the Upper Jaguaribe Basin, Brazil. Journal of Soils and Sediments, 14: 1938-1948, 2014.

PIAUÍ. Secretaria Estadual do Meio Ambiente e Recursos Hídricos (SEMAR-PI). Projeto Básico de Adequação do Sistema Adutor Bocaina, Memorial Descritivo. Teresina, v. 1, 2011, 54 p.

PIAUÍ. Secretaria Estadual do Meio Ambiente e Recursos Hídricos (SEMAR-PI) Relatório final do serviço de criação de modelo geoidal local para o açude Bocaina-Bocaina no Estado do Piauí Teresina, 2016a, 85 p.

PIAUÍ. Secretaria Estadual do Meio Ambiente e Recursos Hídricos (SEMAR-PI). Relatório de fiscalização. Contrato SEMAR $n^{0}$ 024/2014, Teresina, 2016b, $10 \mathrm{p}$.

REDO, D.; AIDE, T. M.; CLARK, M. L. Vegetation change in Brazil's dryland ecoregions and the relationship to crop production and environmental factors: Cerrado, Caatinga, and Mato Grosso, 20012009. Journal of Land Use Science, 8: 123-153, 2012.

SANTOS, J. C. N. et al. Determinação do fator de 
cobertura e dos coeficientes da MUSLE em microbacias no semiárido brasileiro. Revista Brasileira de Engenharia Agrícola e Ambiental, 18: 1157-1164, 2014.

SILVA, A. M.; SCHULZ, H. E. Hydrosedimentological dynamics on Água Fria Watershed. Brazilian Archives of Biology and Technology, 50: 861 - 870, 2007.

SILVA, R. M.; SANTOS, C. A. G.; MONTENEGRO, S. M. G. L. Identificação de áreas críticas de erosão e estimativa do potencial natural de erosão mediante SIG e sensoriamento remoto. Revista Brasileira de Cartografia, 65: 881-894, 2013.

VESTENA, L. R. et al. Vazão ecológica e disponibilidade hídrica na bacia das Pedras, Guarapuava - PR. Revista Ambiente e Água, 7: 212 $-227,2012$.

WISCHMEIER, W. H.; SMITH, D. D. Predicting rainfall erosion losses. A guide to conservation planning. Agriculture Handbook no. 282, Washington, Department of Agriculture, USA, 1978, $62 \mathrm{p}$. 